\title{
Development of Business Services for Increasing of Enterprises' Innovational Activities
}

\author{
Galina Mikhailovna Kulapina
}

Doctor of Economics, Professor, Volga Region State University of Service, City of Tolyatti Kulapina-tolgas@yandex.ru

\section{Olga Vladimirovna Markova}

Candidate of Economic Sciences, Assistant Professor, Volga Region State University of Service, City of Tolyatti markovaolga@yandex.ru

\section{Doi:10.5901/mjss.2015.v6n3s2p625}

\section{Abstract}

This article is demonstrating topicality of intellectual servicing of business for increasing its innovational activity. Organizational forms of building networks for companies that provide innovational service have been defined, basing on creation of centralized structure.

Keywords: business intellectual services, consulting, virtual services, innovational process, innovational activity, human factor, intellectual potential, network approach to organization of intellectual service.

Currently the majority of Russian scientists and practitioners realize that import substitution require significant increase of enterprises' competiveness. It may become real only in conditions of their innovational development in all types of their main and infrastructure activities.

As it is known, any process consists of three main stages: input (resources), transformation (action) and output (result). As well as the process of innovational development includes three components: innovational potential, represented by resources, innovational activity (activity, directed on transformation of resources into new product or service) and innovational capital (elevation of market share). At the same time, as it is shown on Figure 1, transformation of innovational potential into corresponding capital is performed on the base of usage of human and informational resources. It is human sources in terms of usage of their intellectual potential for transformation (actualization) of information that are the base of any innovational process. Only human resources may perform purposive actions that may change the situation. In this connection, let us dwell on peculiarities of the concept "innovational activity".

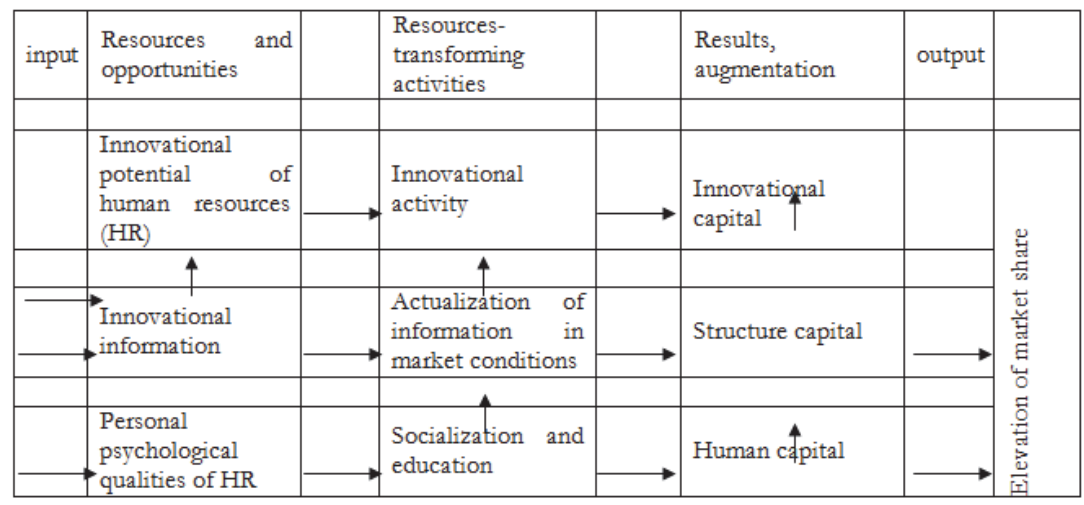

Figure 1. Components of innovational process.

The notion "innovational activity" characterizes degree of development of economic entity's innovational activity. All types of activities, including innovational one, should be characterized by certain effectiveness, since they require resources' 
expenditures and lead to a certain result. Potential of company's activity shows the connection with planned content of the activity and its results. Thus, differences in innovational activity explain different innovational results at equal initial conditions (objectives, plans, resources and potential).

Innovational activity is determined by intensity level of innovational actions on the base of mobilization of innovational potential for achieving competitive advantages on using external and internal developmental factors (Lebedeva, 2010).

Innovational activity is determined by two individual indices:

- Correspondence of economic entity's reaction to character of competitive strategic situation;

- Speed (pace) of actions and implementation of strategic innovational transformations (Trifilova, 2012).

Thus, in conditions of developed market relations innovational activity is characterized by the level and speed of flexible reaction on changes that happen in external and internal environment. In this case innovatively active enterprise would mean any open and adaptive economic system, the number of which in Russian is too small so far. This is proved by statistical data as well. Thus, picture 2 demonstrates shares of enterprises of Volga federal district (VFD), which implement innovations in the lump of economical subjects.

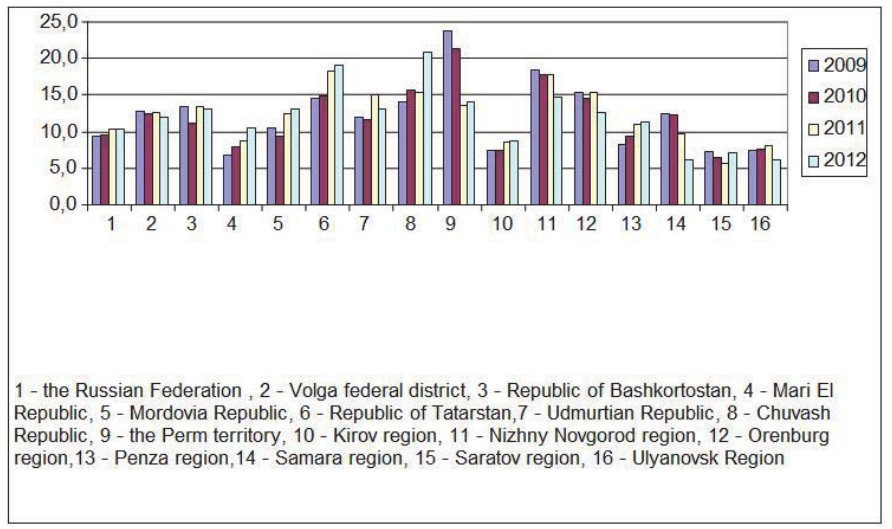

Figure 2. Proportion changes of organizations per subjects of VFD, which implement innovations (http://www.samarastat. ru/digital/nauka/osnpokaz)

Data presented on the picture show that there is no stable growth of organizations that implement technological, organizational and marketing innovations in subjects of VFD, and seven of them (50\%) even demonstrate negative growth. At the same time, such negative dynamics affected innovational activity in the whole Volga federal district.

Besides, innovatively active enterprises in Russia differ markedly from western ones, since western enterprises have long worked in conditions of highly competitive market, filled with quality products. Russia demonstrates substantial gap to quality standards of international market. Considerable part of new products are new for Russian market only and is not able to meet competition; adjusting it to global standards requires such amount of costs and efforts, which are not affordable for many enterprises. In this connection the question of implementation of so-called open innovations is extremely topical, and this process implies involvement of third-party practices and know-how, as well as transferring of one's own practices into external environment.

For modern Russian companies in conditions of economy's globalization and Russian's accession to the WTO there is an urge of using open innovations, when all possible participants of organization's internal and external environments are involved into innovational process. In result of such cooperation innovational potential and companies' activity increase, in the best way reserves of innovational growth are used, while creating synergy effect.

Open innovations are directed to both usage of internal innovational resources and assimilation of external resources. The most important side of the process implies using knowledge, which is actual for current market situation. Time for generation of new knowledge is limited, so it is essential to integrate already available practices and competences and lead them to commercial result with the purpose of obtaining competitive advantages. The founder of "open innovations" concept Henry Chesbrough writes: "Companies that are able to temperate external ideas for promotion of its own business, while furthering its own internal ideas beyond the limits of one's current operations, will be 
able to get ahead in the new era of open innovations" (Chesbrough, 2007). Positive example of applying new innovations is demonstrated by China. Besides industry globalization this county is world's participant of research-and-development activity and is a growth driver of open innovations all around the globe.

Company's innovational openness implies joint activity of all parties that are interested in commercialization of innovations. This process involves not only manufacturers, but also their partners, consumers, which form and effectively realize joint solutions on innovational activity. Approach to taking joint decisions of manufacturers and consumers was called "prosumerism". Unfortunately, open innovations are not enough developed in Russia because of low cooperation level between domestic manufacturers. In this situation rendering of business intellectual services may help. It appears that in the near term the development of management consulting for innovational growth of economic subjects will follow the following directions.

First, one should differentiate between sphere of intellectual services and sphere of creative consulting, which is oriented at specific problem and which requires situational approach.

Second, essential task of management consulting should be collection, systematization, distribution and usage of knowledge by consulting companies and independent consultants for development of territory's economic systems. For this task they will needs to create and use joint infrastructure, represented by Innovational Consulting Center (ICC), which would allow them to achieve synergy effect in carrying out of innovational changes, while cooperating with clients enterprises.

Third, management consulting should create development system for managers of enterprises to boost their ability to act quickly and effectively, which would be based on coaching principle. In the process of diagnostics, improvements' engineering and implementation of programs enterprises' managers and specialists together with providers of intellectual services will be gaining abilities to carrying out recurrent positive transformations in organization, to decreasing resistance to planned changes and to creation of system of initiative and creativity development of all enterprise's personnel.

Foreign new management philosophy has shown that competition is won not by individual companies, but those that were able to take advantage of intercompany cooperation, to set business connections with resources' providers and consumers of goods and services, with staff and consulting centers, to enter into various structures of cooperation. Building on that, we consider creation and functioning of municipal and regional Innovational Consulting Centers (ICC) to be an important measure of enterprises' organizational development in the region. In modern conditions "network" organizational model has been practically spread. It is coordinated from the center that provides centralized organization. Center is connected with various participants, which perform specialized functions and are interconnected with each other. Centers that are created around the nucleus of managers and specialists use the services, rendered by external subcontractors and part-time workers.

The aim of creation of such Center follows its name. Its tasks would include: forecasting on market situation and defining needs in innovations; investigation and introduction of domestic and foreign progressive management practices with the aim of anticipating its adaptation to acceleration of scientific and technological progress and other changes in external environment; rising management culture and increasing quality of goods and services; recurrent professional development of personnel and boost of its creative activities; extension of relations between the companies, and connections with scientific society and with public and social institutions.

ICC's activity and its personnel's sustentation would be financed at the account of Center's incomes, received as a result of consulting and other business services and execution of activities by agreements. It is rational to foresee direct dependence of payroll rate for ICC's specialists with its participation in obtained income by means of bonus system. It means that constant part of consultants' salaries is not supposed to be high, while bonus part may several times exceed constant part, in case significant innovational contribution is made into incomes of client enterprises. ICC would independently define its structure and number of workers, would form subdivisions with consideration of companies' needs in the city, which enter business contracts with. The main organizational form of consultants' activity would be temporary creative consulting groups with co-working office for performance of particular tasks of clients. Certainly, ICC must provide such services that would provide economic and social efficiency of local business' activity, based on boosting its competiveness.

While speaking about the necessity of developing business service, experts emphasize that in current conditions special attention should be paid to primary development of management infrastructure (Kulapina, 2005; Lapygin, 2003; Tkalich, 2007). First, it creates favourable environment for quality functioning of all economic areas; second, it favours formation and close cooperation of all elements of infrastructural complex itself. However, mental structure of most domestic managers and specialists is still directed to finding money, obtaining credit resources for the purposes of new buildings, reconstruction and rearmament. Note that all this is done when there is a large stock of idle equipment and a lot of idle enterprises in Samara region and city of Tolyatti. 
In our opinion, the main role of innovative consulting services should consist in organizational diagnostics of problems, search for the reasons, place and time of their appearance, development trends and revealing their influence of general results of company's activities. Preparation of programs and solution programs or adaptation available solutions to conditions of client organizations should be performed by partners of management consultants that provide intellectual business services, who are experts in functional areas. Thus, consulting management will play international role and will become an interlink between innovational business needs in intellectual services and particular service for their satisfaction. Essential conditions for organization of intellectual servicing are provided in Table 1.

Table 1. Conditions for organization of intellectual servicing

\begin{tabular}{|c|c|}
\hline Freedom of Choice & General Responsibility \\
\hline Broad access to information & Pавенство и разнообразие \\
Freedom of enterprise & Volitional education system \\
Liberalization of working groups & Democratic self-government \\
\hline Limited corporative government & \\
\hline
\end{tabular}

Let us examine principles, conditions and peculiarities of building and functioning of network intellectual organization, based on Innovational Consulting Center (ICC). We suggest such net form of organization for effective functioning of ICC. This net form would consist of many various, partially independent companies, rendering intellectual services.

With such form of partnership intellectual services companies (ISC) would have common informational and technological base and will be served by unite methodological center, which would provide scientific and technological support for their researches. Suggested organizational form is intended to keep balance between ISC's autonomy and control. Each ISC should work independently for acquiring maximum income and be autonomous enough in order to be able to take decisions timely. At the same time, ICC gains success when ISCs that are parts of the Center, cooperate in areas that are common for everyone. The purpose is that such cooperation favours growth of creativity, productivity and quality of rendered intellectual services. Since the Center, being net and even virtual organization, is supposed to be created for rendering intellectual services to business entities, this organization itself should be referred to as intellectual organization. According to opinion of B.Z. Milner, "Generalization of accumulated expertise allows detecting key conditions for intellectual organization's activity. Such conditions are interconnected: taking advantage of high level of freedom and rights is performed along with stable unity and reasonable controllability" (Milner, 2003).

Furthermore, since the Center will be functioning as an open system for solving market issues of business entities, it may be referred to market intellectual enterprise (MIE). We suppose that there would be some typical roles, which it would play in the process of cooperation with ISC and independent clients with the aim of anticipatory adaptation of the latter to future changes in external environment (look Table 2):

Table 2. Typical ICC's roles as MIE varieties

\begin{tabular}{|l|l|}
\hline \multicolumn{1}{|c|}{ Role of the Center } & The essence of the role \\
\hline Creator of knowledge & $\begin{array}{l}\text { Creates knowledge for consultants with regard to share of this consumers' category by means of } \\
\text { collecting information from every available source and formation of special knowledgebase. }\end{array}$ \\
\hline Communicator & $\begin{array}{l}\text { Distributes knowledge on the scale of all network organization, understanding that trust relationships } \\
\text { encourage clients to take part in polls concerning quality of services and allow obtaining additional } \\
\text { information regarding their demands and new orders. }\end{array}$ \\
\hline Strategist & $\begin{array}{l}\text { Performs strategic management of communication channels. Since all the channels are } \\
\text { interconnected with one and the same information, the client may use any of it to contact Center } \\
\text { regarding any question. For strategic planning the Center uses methods of future situations' analysis } \\
\text { (PEST and SWOT analysis), management on weak signals etc. }\end{array}$ \\
\hline Innovator & $\begin{array}{l}\text { Develops technologies on his own and uses available best practices for obtainment and processing } \\
\text { of information, turning it into knowledge, develops and uses new technologies and non-standard } \\
\text { management solutions for processing clients' orders. }\end{array}$ \\
\hline Integrator & $\begin{array}{l}\text { Applies intellectual potential of all the workers of network organization in the process of their } \\
\text { cooperation and creation of new knowledge links, which may quickly spread and be used in needed } \\
\text { directions, creating synergy effect. }\end{array}$ \\
\hline
\end{tabular}

In our opinion, success in management innovative consulting requires balance between centralization and 
decentralization of such net organization. Net intellectual organization is a flexible, sometimes temporary cooperation between service providers. It represents dynamic structure, main components of which may be added or removed according to changed clients' demands or external factors. The main advantage of networks that each participant may focus of that type of activity, which he gained the best results in. Members of net organization are tied not with traditional hierarchic relation, but with contracts and shared objectives.

Many foreign organizations raised network's work to the level when barriers between the company, its clients and competitors are erased; network may become broader or narrower as and when required. Synergy effect is achieved, since all the participants of the network discharge well-defined responsibilities, mutually complementing each other, while the quality and effect of the work increase. At the same time, some ISC manage to dispose of some types of activities or particular operations that may be performed by other participants of the network on higher level.

The most important result of combination of numerous and various types of knowledge of companies that render intellectual services would be so-called virtual service. This is a new process, associated with usage of intellect, highspeed processes, technologies of innovative software etc. Pre-requisite for rendering virtual service is integration of information and knowledge and introduction of corporation of a new type. In order to create virtual service, the company needs to continuously control large amounts of information, to acquire new knowledge and skills.

Innovational development of enterprises requires additional investments, when investors wish to be confident of timely payback of their investments. As a rule, financial results of company's activity reflect current situation, but not the future one, that's why investors and creditors search for indicators that allow predicting organization's success in future. In developed market economy such indicator is represented by company's ability to perceive innovations and act quickly in correspondence with changing external environment. Thus, intellectual servicing becomes key source of creation of stable competitive advantages for the enterprises, basing on their continuous innovational activity and increasing of innovative activity.

\section{References}

Chesbrough Henry. Open Innovation: The New Imperative for Creating and Profiting from Technology. - Moscow: Publishing house "Pokoleniye", $2007-336 \mathrm{p}$.

Kulapina G.M. Development of managing consulting as a service sector for small and medium business of the region. - Tolyatti: Volga University named after Tatischev V.N., 2005. - $148 \mathrm{p}$.

Lapygin Yu.N. Management consulting / Teaching guide -revised and enlarged edition No. 2. - Vladimir: Vladimir State Pedagogical University, Vladimir Institute of Business, Vladimir State University, 2003. - 187 p.

Lebedeva N.N. Innovational activity of enterprises as a pre-condition of their competiveness / N.N. Lebedeva // Journal of institutional studies. - 2010. - Vol.2. - No.4. - p.15-21.

Milner B.Z. Managing knowledge: Evolution and revolution in organization. M.: Infra-M, 2003. -177 p.

Tkalich A.I. Consulting service: Teaching guide / A.I. Tkalich. - M.:Alpha-M, 2007. - 207 p.

Trifilova A.A. Open innovations and development of key functional areas of management of company's innovational activities // Innovations. No.3, 2012. 90-100 p. 